\title{
VIDA Y MUERTE DE UN MAESTRO DE CANTO LLANO DE LA CATEDRAL DE SEVILLA EN EL SIGLO XVI: EL TRATADISTA LUIS DE VILLAFRANCA ${ }^{1}$
}

\section{LIFE AND DEATH OF A PLAIN CHANT MASTER OF THE CATHEDRAL OF SEVILLE IN THE $16^{\text {TH }}$ CENTURY: THE THEORIST LUIS DE VILLAFRANCA}

Clara Bejarano Pellicer

Universidad de Sevilla

\begin{abstract}
Resumen
Este trabajo se propone trazar el perfil sociológico de Luis de Villafranca, maestro de capilla en funciones y maestro de mozos de coro en la catedral de Sevilla del siglo XVI, fundamentalmente a través de fuentes notariales, prestando especial atención a su testamento. La influencia que ejerce la actividad musical sobre el perfil social de una persona y viceversa en el siglo XVI español es el principal interés de esta investigación.
\end{abstract}

\section{Palabras clave}

Maestro de capilla, capilla musical, catedral de Sevilla, mozos de coro, testamento, inventario de bienes, cofradía, asilo.
El estudio de los músicos como grupo social, al margen de la creación compositiva, ofrece un interés musicológico fuera de toda discusión en la medida en que hace una importante aportación a la historia social de la música. La documentación privada, cruzada con la institucional, permite descubrir a aquellas figuras que, aunque no fueran autoras de grandes obras musicales ni intérpretes renombrados, contribuyeron a la historia de la música en la Edad Moder-

\begin{abstract}
This paper tries to draw Luis de Villafranca's social profile, who was an acting chapel master and altar boys teacher in the sixteenth-century cathedral of Seville, basically through notarial sources, paying special attention to his will, that shows -with attached documents- a different death date from known. The influence exerted by musical activities over a person's social profile and vice versa in the Spanish 16th century is the main interest of this research.
\end{abstract}

\section{Key words}

Choirmaster, chapel, Sevillian cathedral, altar boys, will, inventory, brotherhood, old people's home.

na al alimentar la vida musical de una capilla, la formación musical de sus integrantes y el tejido musical de la ciudad. Desde los años 80, gracias al influjo de corrientes renovadoras como la Nueva Historia Cultural y la Historia de la Recepción Musical, se empieza a reconocer el interés científico que presenta la reconstrucción de las condiciones sociales, laborales y económicas en las que las composiciones musicales tuvieron su aplicación. La dimensión social de los

1 Trabajo que se inscribe en el Proyecto I+D «Andalucía en el mundo atlántico: actividades económicas, realidades sociales y representaciones culturales (siglos XVI-XVIII)». HAR2013-41342-P. Dicho Proyecto está financiado por la Subdirección General de Proyectos de Investigación del Ministerio de Economía y Competitividad. 
músicos del Antiguo Régimen ya cuenta con sólidos acercamientos, en nuestro país y en el extranjero. ${ }^{2}$ No obstante, las figuras de los cantores y tratadistas han sido las que más desapercibidas han pasado, en favor de maestros de capilla y ministriles.

Luis de Villafranca ha sido escogido como caso de estudio gracias a la abundancia de documentación que se conserva sobre su vida privada, pero no se trata de un individuo excepcional en este sentido. Sobre muchos de los músicos anónimos del siglo XVI existen innumerables documentos que duermen inéditos en los fondos archivísticos, dispersos en una masa documental por explorar. Muy al contrario, la de Luis de Villafranca es una figura que pasa fácilmente desapercibida debido a que sus actividades fueron más docentes que compositivas y, como veremos, bastante representativa del amplio abanico socioprofesional que se ocupaba de las necesidades musicales de la sociedad. El interés de su biografía reside en proponer unas tendencias sociales para el conjunto de los músicos catedralicios y contrastarlas con otros casos conocidos para averiguar cuán determinante fue el oficio de la música en una trayectoria vital. Si hay que adscribir a Luis de Villafranca a alguna especialidad musical concreta, en la documentación catedralicia de Sevilla, Luis de Villafranca consta como maestro de capilla, pero principalmente como maestro de mozos de coro y docente de canto llano entre 1545 y 1579. Podemos tomarlo como representante de los profesionales de la música sacra, del personal de las capillas catedralicias o de los músicos urbanos por extensión.

\section{CARRERA PROFESIONAL}

La noticia más temprana que se conoce sobre Luis de Villafranca como maestro de capilla es la del 7 de junio de 1532, y aparece en las actas capitulares de la catedral de Plasencia. Cristóbal de Morales había abandonado su puesto al frente de la capilla musical desde 1531, aunque se ignoran las razones. Su primer sustituto sólo duró unos meses en el cargo, y el segundo fue Luis de Villafranca, aunque a su vez fue sucedido por Hernando Díaz el 3 de octubre de 1534. Es una lástima que las actas capitulares no ofrezcan más información sobre las circunstancias de su incorporación a

2 Por citar ejemplos significativos en una relación no exhaustiva, mencionemos por orden cronológico a EDLER (1983). GÓMEZ PINTOR, 26 (Granada, 1995): 27-46. SIEMENS FERNÁNDEZ, 23, 1 (Zaragoza, 2007): 109-128. GRANGER (2002). REYNAUD (2004): 241-252. MARÍN LÓPEZ (2005): 115-144. RUIZ JIMÉNEZ (2005): 150-151. MARÍN LÓPEZ (2006): 425-458. GEMBERO USTÁRROZ (2007): 17-58. BEJARANO PELLICER (2013). la plantilla y de su abandono. ${ }^{3}$ Es probable que se trate del mismo Luis de Villafranca que más tarde encontramos trabajando en la catedral de Sevilla, porque debía de contar con formación, capacidad y alguna experiencia para que tuviera confiadas las funciones de maestro de capilla en 1545. Por otro lado, no resulta nada extraño observar el ascenso de un músico en la jerarquía que formaban las catedrales españolas, con la de Sevilla, entre otras, en la cúspide. ${ }^{4}$

En efecto, en esa fecha Luis de Villafranca aparecía en el libro de salarios de la catedral de Sevilla como maestro de capilla, y debió de ser recibido ese mismo año pues cobró un salario prorrateado de 6 fanegas y 6 almudes de trigo en grano. ${ }^{5}$ Su salario al año siguiente era completo y se cifraba en 8 fanegas. ${ }^{6}$ El maestro de capilla titular era Pedro Fernández de Castillejo, el cual ya estaba mayor y achacoso. De ahí que Bernardo de Villalba se encargara de los seises en su lugar desde 1540 y que Luis de Villafranca desempeñara el papel de maestro de capilla desde 1545, con sus correspondientes remuneraciones. En 1551, sería el cantor Francisco Guerrero quien recibiría la tarea de la educación de los seises. ${ }^{7}$

Luis de Villafranca se convirtió en maestro de los mozos de coro y docente de canto llano en el mismo año que ejercía de maestro de capilla, en 7 de marzo de 1545, con un salario de 8.000 maravedíes y 16 fanegas de trigo. Juan Martínez, que había desempeñado el cargo antes que él desde 1525 y había publicado el Arte de canto llano en 1532, recibió en febrero tan sólo dos meses de salario ( 9 fanegas de trigo), señal inequívoca de cese. ${ }^{8}$ Villafranca tuvo asignado con un salario muy discreto, poco apropiado para la responsabilidad de su cargo y no comparable con el de los demás miembros de la capilla. A pesar de una interrupción en la serie documental, comprobamos que Luis de Villafranca seguía desempeñando el cargo en 1561, ya con un salario de 16.000 maravedíes, 32 fanegas de trigo y 16 de cebada. ${ }^{9}$ Sin embargo, esto debió de ser una acumulación de dos salarios pendientes, porque en ese y en los siguientes años las cifras se reducirán a la mitad: 8.000 maravedíes, 16 fanegas de trigo y 8 de cebada. ${ }^{10}$ Gracias a algunos aumentos acordados por el cabildo en 17 de octubre de 1565, al año siguiente ya cobraba 20.000 maravedíes, 40 fanegas de trigo y 16 de

3 STEVENSON (1993): 29. MOLL ROQUETAS, 8 (Barcelona, 1953): 3-26.

4 RUIZ JIMÉNEZ (2004): 199-242.

5 Archivo de la Catedral de Sevilla (ACS), Sec. IV Fábrica, libro de salarios 322, fol. 13 r.

6 ACS, Sec. IV Fábrica, libro de salarios 322, fol. 25r.

7 STEVENSON (1993): 169.

8 ACS, Sec. IV Fábrica, libro de salarios 322, fol. 5v.

9 Ibídem, fol. 40r.

10 Ibídem, fols. 55r, 91v, 122v, 142v. 
cebada. Este aumento de 6.000 maravedíes y un cahíz de trigo es atribuido por Stevenson ${ }^{11}$ a la publicación que había realizado ese año de un conciso manual de canto llano llamado Breve instrucción de canto llano. ${ }^{12}$ Esta cartilla era la mejor de carácter didáctico del panorama musical en su género y recibió los parabienes del maestro de capilla, Pedro Fernández de Castillejo, y de Francisco Guerrero, cantor, maestro de seises y futuro maestro de capilla. ${ }^{13}$ Fue su única obra publicada, aunque se concibió como el preámbulo de un segundo tratado más ambicioso, que abarcaría también el canto de órgano y el contrapunto, y que jamás llegó a escribirse. ${ }^{14}$ Por otra partida, la de Fábrica, le debían de pagar cada año 10.000 maravedíes, 20 fanegas de trigo y 8 fanegas de cebada adicionales. ${ }^{15}$ En 9 de septiembre de 1577 se le concedió un nuevo aumento de maravedíes para actualizar su remuneración ${ }^{16}$ por lo que al año siguiente pasó a ganar 25.000 maravedíes, 40 fanegas de trigo y 16 fanegas de cebada por una partida, y 12.000 maravedíes, 20 fanegas de trigo y 8 fanegas de cebada por la otra. ${ }^{17}$

Cualquier intérprete de la capilla musical catedralicia (fuese cantor, ministril, campanero u organista) ganaba mucho más que él, puesto que sus salarios en 1561 oscilaban en un arco entre los 20.000 maravedíes con 12 fanegas de trigo del organista del Sagrario, y los 80.000 maravedíes y 84 fanegas de trigo del cantor bajo Tomás de Jaén y otros cantores que le sucedieron. Por debajo del salario del maestro de mozos de coro sólo estaba el afinador del órgano. Gracias a la adición de 1565 , consiguió igualar y superar a los más humildes de los músicos, pero la mayoría continuaba ganando muchísimo más dinero que él. A destacar determinados cantores, que superaban los 100.000 maravedíes. ${ }^{18} \mathrm{Si}$ de una fanega podía conseguirse 60 libras de pan en flor, el de mejor calidad, y los pobres comían unas 3 libras diarias (a falta de más variedad en su dieta), en ese caso una fanega bastaría para que el maestro comiera 20 días, pero hay que tener en cuenta que, como veremos, no vivía solo. Las clases humil-

11 ACS, Sec. I Actas Capitulares, libro 27, fol. 175. Cit. por STEVENSON (1985): 53.

12 VILLAFRANCA, Luis de: Breve instrucción de cantollano para aprender brevemente el artificio del canto, como para cantar epístolas, lecciones, profecías y evangelios y otras cosas que se tratan, conforme al estilo de la Santa Iglesia de Sevilla. Sevilla, Sebastián de Truxillo, 1565.

13 ACS, Sec. I, Actas Capitulares, tomo 1564-1566, fol. 175r. STEVENSON (1993): 178.

14 MARTÍN GALÁN (2002): vol. 10, 909

15 ACS, Sec. IV Fábrica, libro de salarios 322, fols. 154v, 162v, $166 \mathrm{v}, 172 \mathrm{v}, 176 \mathrm{v}, 181 \mathrm{v}, 184 \mathrm{v}, 189 \mathrm{v}, 192 \mathrm{v}$.

16 ACS, Sec. IV Fábrica, libro de salarios 323, fol. 66v.

17 Ibídem, fols. 76v y 81r.

18 ACS, Sec. IV Fábrica, libros de salarios 322 y 323. des se caracterizan precisamente por vivir prácticamente al día, no teniendo apenas reservas. ${ }^{19}$

Además de ser uno de los salarios más pobres que dispensaba el cabildo al personal musical, significaba para Villafranca un poder adquisitivo más bien bajo. Tengamos en cuenta que en 1561, cuando él no ganaba más que 13.984 maravedíes al año por su cargo de maestro de mozos de coro, una gallina costaba 80,6 , una arroba de aceite 273,2 , un libra de cera amarilla 76 y una arroba de vino 102 . En 1565 sus ganancias ya montaban 48.660 maravedíes, casi el cuádruple, pero hay que tener en cuenta la subida de los precios que comportaba la economía atlántica sevillana: la gallina costaba 86,8 maravedíes, la arroba de aceite 289 , la libra de cera amarilla 82,4 y la arroba de vino 133 , 4. En 1577, cuando su salario ganó 7.000 maravedíes más, una gallina costaba casi 100 , la arroba de aceite 277 , la libra de cera amarilla 106,3 y la arroba de vino $136 .{ }^{20}$ Por lo tanto, se puede decir que la capacidad adquisitiva del maestro fue progresando al ritmo de los aumentos de salario, que están justificados por la inflación sólo hasta cierto punto, y que fueron los más discretos de la plantilla musical, por lo demás.

¿Quiénes eran los destinatarios de sus esfuerzos como docente? Los mozos de coro no deben ser confundidos con los seises o niños cantorcillos. Eran jóvenes de 10-16 años que desempeñaban tareas de monaguillos o servidores en las celebraciones litúrgicas, su educación musical se limitaba al canto llano y no vivían en casa del maestro de capilla. ${ }^{21}$ En época del maestro Villafranca eran dieciocho los mozos de coro. Recibían un salario semanal exiguo. A principios del siglo XVI era de 18.000 maravedíes de la Mesa Capitular para el conjunto de los mozos de coro. El arzobispo fray Diego de Deza amplió el presupuesto a 30.000 maravedíes. ${ }^{22}$

Se encargaban del servicio del altar y coro como acólitos, pero también cuidaban y ordenaban los papeles y libros de música, limpiaban el coro y cuidaban los utensilios del altar. Al estar capacitados para interpretar gregoriano, algunos formaban parte del coro en el oficio, cantaban maitines, podían ser clérigos y ocupar una capellanía. Cantaban la antífona Santissimae Trinitatis junto con los seises y los cantores adultos todos los días después de Prima y antes de Vísperas, excepto en el Triduo Pascual, a causa de una fundación testamentaria de 1498 del arcediano de Écija Pedro Mejía, para lo que dejó 7.000 maravedíes. También les correspondía cantar la Salve de los sábados en la capilla de la Antigua, en virtud

19 RODRÍGUEZ VÁZQUEZ (1995): 64-66.

20 HAMILTON (1983): 354-355.

21 DE LA ROSA Y LÓPEZ (1904): 27. STEVENSON, Robert (1993): 178

22 DE LA ROSA Y LÓPEZ (1904): 42. 
de otra fundación de 1498 del obispo de Málaga Diego de Toledo, pero con el tiempo fueron desplazados por la capilla musical.

Al principio del siglo XVI eran estudiantes manteístas, vivían en sus domicilios y sólo acudían a la catedral para desempeñar su cargo. En el Estudio de San Miguel se formaban con el resto del clero sevillano: por las mañanas aprendían canto llano, latín, doctrina y ceremonias, y por la tarde lectura y escritura. En 1526 el arzobispo Alonso Manrique fundó el colegio de San Isidoro, vulgo del Cardenal, para la formación del clero, que hasta entonces asistía al estudio de San Miguel. El Arzobispado y la Catedral se aliaron para mantener a una veintena de jóvenes colegiados, en régimen interno: los que vestían opas pardillas seguirían la carrera eclesiástica y los de las opas moradas o azules eran los mozos de coro de la catedral. El alojamiento de éstos últimos en este colegio sólo fue efectivo en el período comprendido entre 1532 y 1538 , y al morir el cardenal volvieron a sus casas. Recibían clases de varios profesores especializados: canto llano, derecho canónico, ceremonias, canto de evangelios, epístolas y lecturas. ${ }^{23}$

La figura del maestro de mozos de coro apareció en la segunda mitad del siglo XV y solía ser seleccionado mediante concurso oposición presidido por el maestro de capilla. $\mathrm{Su}$ estilo al enseñar el canto llano marcaba la forma en que la catedral lo ejecutaba. ${ }^{24}$ Sus funciones están perfectamente caracterizadas gracias a los Estatutos de la Catedral de Sevilla de 1550, a los que el arzobispo Valdés hizo adiciones en 1563, y también gracias al reglamento que se publicó en la capilla de San Nicolás en 17 de noviembre de $1598 .{ }^{25}$ Además de cantar en el coro, daba clase de gregoriano en latín todos los días laborables por la mañana y la repetía por la tarde junto con clase de lectoescritura, en la capilla de San Nicolás (situada en el claustro occidental del patio de los Naranjos) para los mozos de coro y para cualquier miembro del personal de la catedral. Debía estar presente también si la lección era impartida por su "repetidor". Asistía con sus discípulos a cantar el Sanctisime (del que se hablará enseguida). Era responsable de la corrección y el lugar de su vestuario, el silencio y la compostura de los mozos al servir en las misas, de su confesión y comunión en las principales fiestas, de su asistencia insustituible, sobre todo la de los mayores.

23 DE LA ROSA Y LÓPEZ (1904): 56-57. GONZÁLEZ BARRIONUEVO (2000): 691-701.

24 En algunas catedrales, como la de Coria, en el siglo XVI se identificaba la figura del maestro de canto llano con la del sochantre o director del coro de canto llano. BARRIOS MANZANO, 26 (Granada, 1995): 73-82.

25 ACS, Sec. IX, Fondo Histórico General, 113, doc. 5.
También era responsable de sus progresos: los mozos que no aprendieran lo que se les enseñaba no podrían servir en misa ni cobrar la semana, y era el maestro el que debía informar sobre ello al sochantre, que era el legítimo responsable de los mozos de coro como delegado del chantre. Los días de fiesta debía vigilar que los mozos cumplieran su deber, pues su sola presencia se garantizaba una mayor eficacia. Debía controlar y castigar los abusos de los mozos: las sustracciones de cera y el servicio a los sacristanes.

Después de desempeñar este cargo durante treinta y cuatro años, Luis de Villafranca falleció el 23 de octubre de 1579. Le correspondia, prorrateando su salario de ese año, 20.274 maravedíes, 32 fanegas y 5 almudes de trigo y 12 fanegas, 11 almudes y 3 cuartos de cebada. Le sucedió en su puesto de maestro de mozos de coro el presbítero Gaspar Delgadillo heredando su salario desde el 6 de noviembre de $1579 .{ }^{26} \mathrm{El}$ lunes 26 de octubre el cabildo acordó "poner edictos para probeer el Magisterio de los moços de choro que vacó por Villafranca por tiempo de ocho días". ${ }^{27}$

\section{MUERTE Y TESTAMENTO}

No obstante, a pesar de ser una figura dentro del aparato musical de la capilla catedralicia hispalense, con la documentación que esto genera, la verdadera concentración de información que el maestro Villafranca nos ofrece no es producto de su reposada vida, sino de su muerte. El testamento, el codicilo, el inventario postmortem de bienes y demás documentación derivada del óbito constituyen, además del motor de este trabajo por lo demás, un tesoro para la Historia social del músico en el Renacimiento español. ${ }^{28}$ Es natural que en el testamento de una persona se reflejen sus actitudes vitales y se reconozca su personalidad. No tanto en las palabras, puesto que éstas obedecen a una retórica notarial ritualizada, sino esencialmente en el estado de sus cuentas. Permite investigar no sólo el patrimonio del finado, sino también la gestión que ha llevado a cabo de él, sus inclinaciones y gustos estéticos y algunos rasgos de su personalidad.

26 ACS, Sec. IV Fábrica, libro de salarios 323, fol. 87r. Esta cita explícita, "Fallesció a 23 de octubre de 1579", junto con la localización de su testamento, inventario de bienes y venta de su mula en almoneda pública por parte de su albacea, demuestran claramente que el maestro Villafranca no se jubiló en 1579, como se ha sostenido, sino que falleció en esa fecha y no en 8 de noviembre de 1596 .

27 ACS, Sec. I Actas Capitulares, libro 31, fol. 140. Cit. por STEVENSON (1985): 66.

28 Archivo Histórico Provincial de Sevilla (AHPdSE), Sec. Protocolos Notariales de Sevilla (PNS), oficio 1, leg. 150, libro $3^{\circ}$ de 1579 , 22 de octubre de 1579, fol. 639 . 
El testamento, como documento notarial, desde los años 70 se ha revalorizado historiográficamente porque, bajo una análisis serial de lo corriente y repetitivo, permite obtener conclusiones aplicables al período de larga duración. Aunque se trate de un documento estereotipado, siempre se descubren matices individuales a la vez que refleja el subconsciente general. ${ }^{29}$ Por su parte, el inventario de bienes no se hace por ninguna razón fiscal ni religiosa, sino para averiguar el estado económico de un individuo de cara a la liquidación de sus deudas y el reparto de su patrimonio entre sus herederos. Por lo tanto, es muy excepcional y además aparece sin valoraciones monetarias en más de un $90 \% .^{30}$

El definitivo testamento de Luis de Villafranca se extiende a lo largo de nueve páginas del tercer libro de protocolos de 1579 del oficio $1^{\circ}$ de Sevilla, que parece ser el que el maestro escogió para sus escrituras, entre los 24 que había en la ciudad. No coincide con la escribanía a la que solía acudir la mayoría del personal de la catedral, sino que por el contrario tenía una clientela muy nutrida de perfil artesano, por lo general residente en las collaciones de Omnium Sanctorum y San Juan de la Palma. De hecho, los vecinos de Luis de Villafranca eran un pertiguero de la catedral, un sastre, un labrador... De todas formas, el propio maestro también era vecino de una collación de la zona norte de Sevilla en el momento de su muerte, así es que su fidelidad al oficio 1 podría venir motivada por la vecindad. Pues el testamento comienza diciendo que es vecino de la collación de San Julián, en la calle de Rosas o Granadales, que estaba a las espaldas de una casa que se situaba enfrente de la puerta de la parroquia. Anteriormente, sabemos que había sido vecino de San Andrés en 1568, ${ }^{31}$ que también era una collación situada al centro-norte de Sevilla. Aunque en febrero de ese mismo año ya había adquirido el inmueble de la collación de san Julián en el que moriría, a finales de 1568 todavía no se habría trasladado ya que todavía se titulaba vecino de San Andrés. Ésta es una de las collaciones más pobladas por los músicos sevillanos en el Siglo de Oro. ${ }^{32}$ En 1572 afirmaba ser vecino de la collación de San Martín, la cual cumple los mismos patrones que las anteriores. ${ }^{33}$

En su testamento, Luis de Villafranca se titula maestro de capilla aunque hacía muchos años que no ejercía tal cargo. O bien se sentía más identificado con él que con el de

29 MARTÍNEZ GIL (1993): 17-24.

30 AGUADO DE LOS REYES (1994): 19-20. RODRÍGUEZ VÁZQUEZ (1995): 31. y $907 \mathrm{v}$.

31 AHPdSE, PNS, oficio 1, libro $3^{\circ}$ de 1568 , leg. 117, fols. 849

32 BEJARANO PELLICER (2013): 81.

33 AHPdSE, PNS, oficio 1 , libro $2^{\circ}$ de 1572 , leg. 128 , fols. 290 r295 r. docente de mozos de coro, o bien en aquel momento de balance de su trayectoria vital recurrió a la más prestigiosa de las ocupaciones que había desempeñado, la que había representado el culmen de su carrera como músico. Por otro lado, queda constancia de que no sólo era clérigo, sino que tenía el orden de presbítero. Esto alimenta la hipótesis de que podría haber detentado alguna capellanía o desempeñado funciones no musicales que le permitieran engrosar su salario.

El testamento aparece datado en 22 de octubre de 1579 en la misma casa del maestro, por lo cual sabemos que fue su testamento definitivo. La fecha efectiva de su muerte fue el día siguiente, de acuerdo con las fuentes catedralicias. De acuerdo con la costumbre, el testador esperaba a las puertas de la muerte para hacer el testamento. ${ }^{34}$ Él mismo reconoce que existían otros testamentos precedentes, pero que quedaban invalidados por éste. Después de las cláusulas declaratorias de fe, comienza con las decisorias más habituales. Sus ritos funerarios no le preocupaban excesivamente, ya que deja algunos aspectos en manos de sus albaceas, como la limosna que había de darse. Tampoco tenía preferencias por un templo concreto donde ser sepultado, cosa que deja a decisión del cabildo o en la de sus albaceas, en su defecto. Resulta llamativo que, teniendo en cuenta cuán ligado se sentía el maestro a la cofradía de San Bernardo, a la que pertenecía, no tuviera una preferencia definida en cuanto a sepultura. En cualquier caso, él dispuso que al tomar la decisión al respecto, sus albaceas avisaran a la cofradía. ¿Se trata de una insinuación? Todas las iglesias estaban obligadas a ceder un lugar de sepultura gratuito a sus fieles en el cementerio, pero para ser enterrado dentro del templo era necesario pagar unos derechos a la fábrica, dependiendo de la zona del mismo. ${ }^{35}$ Lo habitual era enterrarse en la propia parroquia, que era lo más barato, mientras que las iglesias conventuales eran signo de distinción. ${ }^{36}$

Los únicos deseos que tenía en cuanto a ritual funerario eran una misa de réquiem cantada y doce rezadas con su cuerpo presente, peticiones en verdad no muy exigentes, el día de su entierro. Lo habitual en su época era efectivamente una misa cantada de cuerpo presente y otras misas rezadas que podían decirse al mismo tiempo en diferentes altares, algunas de ellas con sermones. Después se realizaba un responso y el cuerpo era incensado y rociado con agua bendita para ahuyentar a los demonios. ${ }^{37}$ Naturalmente, Luis de Villafranca se permitía ser tan comedido porque le constaba que como cofrade tenía derecho a otros homenajes por parte

\footnotetext{
34 MARTÍNEZ GIL (1993): 517.

35 Ibídem: 348.

36 Ibídem: 525.

37 Ibídem: 425.
} 
del hospital de San Bernardo. El éxito social de las cofradías residía en la garantía de un entierro y unos sufragios dignos. ${ }^{38}$ Por el contrario, para después de su entierro solicitaba una misa rezada en la capilla de las Escalas de la catedral, ${ }^{39}$ otra en el monasterio de la Victoria de Triana y cien más en la capilla de los Cálices de la catedral. La vinculación del testador con la iglesia mayor es obvia, pero no así la del monasterio de los frailes Mínimos de San Francisco de Paula en Triana. ${ }^{40}$ Estas honras o exequias, ceremonias de los nueve días posteriores al entierro, solían consistir en responso y misa, dejando una ofrenda de pan, vino y cera sobre la sepultura. ${ }^{41}$ El capítulo de mandas pías concluye con las limosnas que casi todos los testamentos reproducen ritualizadamente. Se solía destinar medio real para cada uno de los siguientes templos: la catedral, la ermita de san Sebastián del Campo, el hospital de San Lázaro, ${ }^{42}$ el convento de la Merced y el de la Santísima Trinidad. A su vez, debía ofrecer cuatro reales de cera al Santísimo Sacramento y dos a la fábrica de la parroquia donde residía su cofradía, que era la de San Juan. Estas limosnas, que solían ser de medio real pero que con el avance del siglo XVII se incrementaron, se traducían en misas rezadas. ${ }^{43}$ Se trata de un entierro austero, con una sepultura por determinar, sin mención a la cera, ni al ataúd ni al hábito, sin muñidor, pobres, niños de la Doctrina, músicos y demás acompañamiento.

El siguiente apartado de su testamento, una vez puesto en orden el estado de su alma, se refería a sus finanzas. Sirve como hábil transición entre ambas materias el encargo de trece misas rezadas en una iglesia por determinar -le trae sin cuidado- por el alma de Leonor Muñoz. Esta mujer difunta constituye un misterio en la vida del maestro, puesto que no sabemos qué vinculación tenía con ella. Muchos intitulantes encargaban misas por el alma de sus padres en sus testamentos, pero de esta mujer, la cual usurpa el lugar de éstos en este caso, lo único que sabemos por el mismo testamento es que cuando murió había legado a Luis de Villafranca un tributo perpetuo de 69 reales anuales situados sobre unas casas en la calle de Carreteros en Triana, que quería que él disfrutara antes de que fuera empleado en el culto al alma de ella. Este legado fue a condición de que, en su testamento, él lo legase al monasterio de San Pablo para que se le dijesen a ella treinta misas anuales perpetuamente. Las misas de sufragio funcio-

38 Ibídem: 530

39 COLLANTES DE TERÁN (1890).

40 FERNÁNDEZ ROJAS (2006): 149-186.

41 MARTÍNEZ GIL (1993): 427-429.

42 La función social de este centro ha sido estudiada por MORENO TORAL (1997).

43 MARTÍNEZ GIL (1993): 469-470. naron como una moneda de cambio para la salvación en la Edad Moderna, y en ellas se invirtieron grandes cantidades de dinero que fueron a parar a iglesias y conventos. La cuarta parte debía recaer obligatoriamente sobre la parroquia correspondiente al difunto, pero éste podía disponer libremente del resto. La cantidad de misas encomendadas era tal que no se podían cumplir, al menos en la iglesia. ${ }^{44}$

Una vez comenzada la tarea de repartir su patrimonio, Luis de Villafranca lo diseminó entre varios herederos. Los primeros serían, como es lógico, sus familiares más cercanos: su hermano presbítero Francisco de Villafranca y sus dos sobrinos, ambos hijos de la difunta Inés Ortiz, llamados Juan Ortiz y Cristóbal Tirado. Así pues, Ortiz podría ser el segundo apellido de Luis de Villafranca. A los tres les correspondió una herencia en especie. Francisco de Villafranca recibió la indumentaria de clérigo del maestro -sotana y manto negros de paño-, que probablemente reservaba para ocasiones especiales, ya que estaba nueva y la tenía guardada en un arca ensayalada. A Juan Ortiz le correspondieron unas medias calzas de estameña negra y a Cristóbal Tirado otras, junto con unos calzones a juego.

Pero a estas prendas se sumaron los ahorros que le quedaban de su sueldo en cereal. El último sueldo anual que recibió, el de 1579, en concepto de trigo contenía 60 fanegas. ${ }^{45}$ En su casa almacenaba al menos 18 fanegas de trigo en el momento de su muerte, de las que su hermano y sus sobrinos carnales fueron sus destinatarios. Aunque no podemos precisar exactamente cuánto valían en 1579, en cambio sabemos que en 1580 una fanega de trigo en Andalucía costaba aproximadamente 816 maravedíes, luego aplicando este coeficiente, cada uno de los tres herederos habría recibido cereal por valor de 4.896 maravedíes. En el anexo del testamento, Luis de Villafranca debió de acordarse de que su sobrino tenía un hijo: el talabartero Andrés Jiménez, hijo de Juan Ortiz, también recibió seis ducados (2.250 maravedíes) en efectivo. Aproximadamente la mitad que sus sobrinos en primer grado.

Después de los herederos legítimos, con los que se adivina que el maestro no tenía grandes afinidades, irrumpieron en el testamento los miembros de la familia Alanís, que constituyen los verdaderos herederos de Luis de Villafranca, muy especialmente Beatriz Castaño. Esta mujer, a la que el maestro profesaría mucha gratitud "por buenos serviçios que me a fecho" quizá explicados por la cercanía de sus moradas que estaban situadas en la misma calle, recibió legados de todas las especies.

44 Ibídem: 462-468.

45 ACS, Sec. IV Fábrica, libro de salarios 323, fol. 87r. 
-Textil: el guardarropa de Luis de Villafranca, contenido en la mencionada arca ensayalada. Aunque no se detalla qué o cuántas prendas contenía, sabemos que eran las suficientes como para que ella pudiera ceder algunas a Catalina y Martín, dos hermanos mulatos que, siendo libres, vivían con el maestro.

-Alimentario: salvo las fanegas de trigo mencionadas, los víveres almacenados en casa del maestro fueron confiados a la familia Alanís. La mitad iba destinada a la generación de Beatriz Castaño y la otra mitad a la de Juan de Alanís, su hijo. El testamento menciona pipas de vino y vinagre, tinajas de aceite y aceitunas, trigo, carbón y leña. De todo ello, la cantidad es indeterminada. Solamente se apartaba un simple cahíz de trigo para el hospital de San Bernardo.

-Aviar: puesto que parte de las rentas inmobiliarias en aquella época se pagaban en gallinas, es natural que el maestro pareciera tener un nutrido corral. Los términos del testamento son los siguientes: "todas las gallinas y capones e gallos e palomas e yeros e alpiste".

-Mobiliario: Beatriz Castaño fue la heredera de todos los muebles y aperos que el maestro conservaba en su morada. Se mencionan sillas, mesas y arcas.

-Inmobiliario: Luis de Villafranca legó a Beatriz la casa que él mismo habitaba y poseía en la collación de san Julián. Que tuviera una casa en propiedad, cosa poco frecuente en la Sevilla del siglo XVI, revela el grado de asentamiento y estabilidad profesional que había alcanzado el maestro en la etapa final de su vida. Se trataba de una vivienda unifamiliar, al parecer de dos plantas (a juzgar por la sala baja y alta mencionadas en el inventario de bienes), de cinco estancias incluyendo el corral y la bodega. En el documento de compraventa se describe como "unas casas que tienen su casapuerta e patio e corral e con árboles e cosina e soberados que son e yo tengo ensta çiudad de Sevilla en la collación de san Julián en la calle de Rosas", aunque muy viejas y con necesidad de costosas reparaciones. ${ }^{46}$ Sobre ella existía un tributo o renta perpetua de 6.000 maravedíes anuales a favor de la viuda Leonor de Leiba. Este legado exigía una contrapartida de su vecina: que situara, sobre las dos casas que ella poseía, un tributo de 12.000 maravedíes al año, cuyas rentas se destinarían a mantener una capellanía en el lugar de sepultura del maestro. La fábrica de la iglesia correspondiente recibiría la cantidad necesaria para "vino, cera, ostias, incienso, altar e quien ayude". Además, la renta se emplearía en decir perpetuamente misas rezadas por el alma de Luis de Villafranca y de los difuntos de la familia Alanís, en tantas $766 \mathrm{v}$. festividades como el dinero diese de sí, repartidas por el calendario litúrgico. ${ }^{47}$ En cada una de estas misas, el celebrante debía acercarse a la tumba con agua bendita. El administrador de esta renta debería ser el mayordomo de la cofradía de San Bernardo, quien se encargaría de nombrar y remunerar capellanes. Si Beatriz Castaño no estaba dispuesta a aceptar esta carga, entonces la casa de Luis de Villafranca no le sería legada a ella. En ese caso, el hospital de San Bernardo debía venderla en almoneda y emplear su precio en situar tributos perpetuos o al quitar sobre otras propiedades, con el fin de obtener una renta para la misma destinación.

Efectivamente, en 1582 el hospital de San Bernardo demuestra tener el título de 9.000 maravedíes de tributo perpetuo, situado sobre la casa que Luis de Villafranca había tenido en la collación de San Julián, en la calle de Rosas o Granadales $n^{\circ} 79$, frente a la puerta de la iglesia. En una escritura ante Diego de la Barrera Farfán, relata que Beatriz Castaño rechazó el legado inmobiliario de Luis de Villafranca, el 24 de noviembre de 1581 ante notario. El hospital vendió la casa en almoneda pública al mejor postor, Andrés de Fuente y a su mujer doña Ana de San Andrés, vecino de la collación de San Julián, en 14 de enero de 1582. Éstos debían seguir pagando el tributo perpetuo de 6.000 maravedíes a la viuda Leonor de Leiva (y a sus herederos), y también otro tributo perpetuo de 9.000 por tercios para el hospital de San Bernardo, que era el que había sido dispuesto para costear la capellanía de Luis de Villafranca. Para poder pagar, los compradores hipotecaron una casa que tenían en la Carretería, en la collación de Santa María. Según los pormenores de la puja, Andrés Fuentes la comenzó proponiendo 6.000 maravedíes anuales, sufrió dos oposiciones, y finalmente acabó ofreciendo los 9.000 maravedíes en que se remataron las casas. En 1654 tenemos pruebas de que la capellanía seguía manteniéndose en el hospital, porque éste mantenía pleitos con doña Elvira Jerónima de la Encarnación por no pagar el tributo. ${ }^{48}$

Las cofradías son un producto del asociacionismo urbano de base ciudadana que se formaban en el siglo XVI como respuesta al sentimiento colectivo de inseguridad, ante la carencia de una cobertura asistencial del Estado. En este siglo, el fenómeno creció espectacularmente como una afirmación de identidad religiosa ante el protestantismo. ${ }^{49}$ Los

47 Las capellanías ya existían desde el siglo XIII, pero en la Edad Moderna el fenómeno prosperó mucho como una forma de amortizar bienes. MARTÍNEZ GIL (1993): 474-475.

48 Los documentos relativos a la donación de Luis de Villafranca se encuentran en el Archivo Arzobispal de Sevilla (AGAS), Archivo Hospital de Viejos (AHV), sección II, leg. 46, exp. 79.

49 CARMONA GARCÍA (2009): 12-13. 
hospitales dependientes de cofradías no tenían por qué tener obligaciones asistenciales, sino que muchos de ellos se limitaban a la práctica litúrgico-religiosa y a alguna obra de caridad.$^{50} \mathrm{El}$ de San Bernardo, del cual era hermano el maestro Villafranca, era uno de los más asistenciales, puesto que se dedicaba a mantener a pobres ancianos desvalidos de ambos sexos de más de 60 años, y por eso sobrevivió a la reducción de hospitales que tuvo lugar en 1587. ${ }^{51}$

El hospital de San Bernardo se fundó en 20 de junio de 1355 en la parroquia de Santa Catalina. Se propuso mantener como asilo a 17 ancianos y a 13 ancianas pobres, pero debían ser naturales de Sevilla, mayores de 60 años, preferentemente parientes de los cofrades, honrados y no mendicantes. Una cofradía de 30 sacerdotes sevillanos, entre los que rotaba cada dos años el cargo de administrador, fue la artífice de su fundación, y el presbítero Alonso Sánchez de su dotación. Cuatro de ellos eran prebendados de la catedral de Sevilla. A fines del siglo XIV se fusionó con la cofradía secular de la parroquia de San Juan de la Palma. Entonces experimentó una ampliación y atrajo muchas donaciones populares. No se conservan sus estatutos primitivos, pero sí tenemos documentación a partir de $1545 .{ }^{52}$

Los ingresos de los hospitales procedían de rentas de arrendamientos de casas, donaciones, tributos, y limosnas de los cofrades. Las casas, tributos y juros llegaban a las manos de los hospitales por medio de legados. Los centros dependientes de cofradías eran propietarios de unos 700 inmuebles en Sevilla en el siglo XVI y de los censos que estaban impuestos sobre ellos. ${ }^{53}$ El hospital de San Bernardo recibió 78 dotaciones entre fines del siglo XIV y fines del siglo XVI, lo cual se tradujo en 54 casas, dos huertas y un cortijo en Carmona, más de 100 tributos perpetuos, uno redimible y un juro en el almojarifazgo mayor, un legado de 1.000 maravedíes anuales, y además el hospital compró con su propio caudal un tributo perpetuo que le rentaba 500 maravedíes al año. A cambio de estas donaciones, el hospital tenía dos patronatos bajo su administración perpetua (remunerada con la décima parte de las rentas), once capellanías, la obligación de celebrar muchas misas cantadas, rezadas, de réquiem, aniversarios, vigilias, fiestas y remembranzas, y

50 CARMONA, Juan Ignacio (1979): 43-44.

51 Ibídem: 322.

52 Sobre este hospital escribieron venerables historiadores locales de Sevilla como MORGADO (1981): 369-370. ORTIZ DE ZÚÑIGA (1677): tomo IV, 144. La obra clásica que ha recogido estos testimonios es la de COLLANTES DE TERÁN (1886): vol. II, 257-272. Posteriormente, los autores que han llevado a cabo síntesis actualizadas son CARMONA GARCÍA (2009): 65-66. RUBIO MERINO, 180 (Sevilla, 1976): 1-35

53 CARMONA, Juan Ignacio (1979): 73-75. también tenía que pagar los tributos que gravaban algunas de las posesiones donadas. ${ }^{54}$

El testamento de Luis de Villafranca da a entender que esta encomendación de la administración de su capellanía no sería bien recibida en la cofradía, con una fórmula muy elocuente: "pido y ruego a los dichos señores administrador e cofrades del dicho ospital de san Bernardo açeten lo susodicho e no miren a lo poco que asy les dexo syno a lo mucho que he servido en el dicho ospital e que soy hermano dél". Pero debe de estar empleando una fórmula ritual, porque la lógica dice que el hospital debía de acoger este legado con gran satisfacción. Es cierto que en comparación con los otros dos patronatos que existían en el hospital de San Bernardo, el de Luis de Villafranca no parece ser el más generoso. Los otros cedían la décima parte a la remuneración de su administración, mientras que el maestro concedía dos ducados al año de esta renta, lo cual suponía tan sólo el 6,25\%. Uno de los patronatos conllevaba una capellanía, un aniversario de vigilia y misa cantada, cinco misas rezadas una misa cantada y 12.000 maravedíes al año para un pobre, y lo que sobrara debía destinarse a dotar doncellas pobres con 50 ducados. Estas obligaciones se desprendían de una donación de un tributo perpetuo de 3.420 maravedíes anules, otro redimible de 1.000 ducados de principal, un juro sobre el almojarifazgo mayor y unas casas humildes. El otro patronato estaba dotado con tres casas y un tributo, cuyas rentas deberían destinarse a dotar doncellas pobres (dos terceras partes) y a mantener pobres en el hospital (una tercera parte) ${ }^{55}$

En el testamento también se recogen las deudas a favor y en contra que el maestro tenía en el momento de su muerte. Luis de Villafranca confiesa deber al cabildo $30 \mathrm{du}-$ cados (11.250 maravedíes) en fanegas de trigo, de resto de un préstamo de 80 que se le concedió y se le fue descontando del salario durante seis meses. De hecho, se sabe que le fue concedido el 5 de junio de 1579 y que debía devolverlo en un año. ${ }^{56}$ Mandó pagarlos del trigo que tenía en su casa, poniendo a salvo cuanto antes el patrimonio de su fiador, Juan de Arévalo, para más tarde compensárselo a Beatriz Castaño con lo que rentara su casa. En este punto reconoce que su salario catedralicio era de 100 ducados anuales, lo cual coincide con los libros de fábrica de la catedral.

La naturaleza de esta deuda no tiene nada de particular. El cabildo catedral acostumbraba a tener relaciones crediticias con su personal. Los miembros de la capilla musical

54 Ibídem: 80-81. Archivo Municipal de Sevilla (AMS), sec. V, tomo 190 , exp. 8 .

55 CARMONA, Juan Ignacio (1979): 84.

56 ACS, Sec. I, Actas Capitulares, libro 31, fol. 116v. STEVENSON (1993): 185; (1985): 66. 
son especialmente recurrentes a la hora de solicitar adelantos del sueldo y préstamos en detrimento de su salario. La estabilidad laboral, la seguridad de su remuneración, les permitía un margen mayor de inversión y riesgo que la mayoría de la población. Rara vez el cabildo se negó a conceder un préstamo sin interés, incluso a individuos reincidentes, y era muy flexible en el cobro, pudiendo prolongar el período de devolución..$^{57}$ No siempre se recoge en la documentación el motivo del préstamo, y éste es un caso paradigmático. La presencia de las deudas a favor y en contra es un rasgo común de todos los testamentos porque el préstamo a corto, largo o perpetuo plazo era muy frecuente en la sociedad. Todos prestaban y tomaban prestado continuamente..$^{58}$

El maestro Villafranca también tenía un inmueble del hospital de San Bernardo, situado en la plazuela de las tiendas de la collación de la Magdalena, concedido en arrendamiento por dos vidas. La renta que tenía que pagar al propietario era de 13.500 maravedíes y 26 gallinas al año, la cual era bastante alta en comparación con otras que pagaban músicos sevillanos en $1580 .{ }^{59}$ Puesto que había consumido una vida, legó este arrendamiento por la segunda vida al sastre Juan de Alanís, el hijo de Beatriz Castaño y Diego de Alanís, encomendándole que pagara el segundo tercio de la renta de 1579 y todas las gallinas de ese año, el cual se había cumplido en agosto y todavía lo debía. Eso sí, parecía haber dado ya 6 ducados y 8 gallinas y $3 / 4$ al mayordomo del hospital. Sin olvidar que Luis de Villafranca tenía esta casa subarrendada a un batihoja llamado Montedor, el cual le pagaba 23 ducados al cuatrimestre (esto es, 25.875 maravedíes al año). De ahí que obtuviera rendimiento económico a aquel inmueble a pesar de tener una renta tan alta. El anterior inquilino de esa casa de la Magdalena, Sebastián de Saavedra, le debía todavía 10 ducados (3.750 maravedíes) y algunos reales, de modo que Villafranca pide a Juan de Alanís que los cobre y con ellos salde la deuda que a él le consta que al maestro le queda en la feria de Molares. Ignoramos qué gastos había realizado en este mercado.

También encargó cobrar 86 ducados (32.250 maravedíes) que el anterior propietario de su casa, el presbítero y capellán de la catedral Luis de Medina ${ }^{60}$ (o más bien su heredero, el hospital de la Misericordia), le debía de dos tributos

57 BEJARANO PELLICER (2013): 128-135.

58 RODRÍGUEZ VÁZQUEZ (1995): 54-56. AGUADO DE LOS REYES (1994): 51.

59 Por ejemplo, Antonio Durín, músico de tecla, pagaba 937,5 maravedíes al mes por su casa de la collación de San Juan de la Palma, y el organista Asencio Martín cedía su casa de la collación de san Ildefonso por 612 maravedíes mensuales. BEJARANO PELLICER (2013): 85,505 .

60 AHPdSE, PNS, oficio 1, $3^{\circ}$ libro de 1571, fol. 190. que estaban sobre la casa donde el maestro vivía y que él había redimido tiempo atrás. La viuda Leonor de Leiva había sido la primera ocupante de ese inmueble, pero en 1558 lo cedió a la viuda Inés de Arriaga a cambio de un tributo de 6.000 maravedíes al año. Inés de Arriaga y el capellán presbítero Luis de Medina legaron la casa a su sobrina, Isabel Vázquez, en marzo de 1567 cuando se casó con 19 años con el bonetero Juan de Chillas, y ésta se lo vendió a Luis de Villafranca en 18 de febrero de 1568 por 40 ducados, 41 reales y 6 maravedíes, ${ }^{61}$ por cierto sin mencionar la existencia de los dos tributos, que tuvo que redimir él, sumándole seis ducados más. Sabiéndose estafado, Luis de Villafranca siempre intentó que Luis de Medina, que era quien había situado esos dos tributos, le pagase por la operación que se había visto obligado a hacer, pero no lo había conseguido antes de la muerte de éste. Luis de Villafranca mandó repartirlos, cuando se hubieran cobrado, en cuatro porciones iguales de 21 ducados y medio, entre Juan de Alanís, Andrés Mejía, su sobrino Juan Ortiz y el hijo de éste, Andrés Jiménez, que era talabartero. Los censos, juros y tributos eran muy populares en aquella época porque suponían una inversión rentable y segura, además de honorable. Era una de las pocas fórmulas para ganar dinero sin trabajar: percibiendo una renta sin que mediase labor socialmente indigna.$^{62}$

Así pues, el balance entre deudas a favor y en contra es claramente favorable para el maestro: mientras que le deben 119 ducados, él tiene que pagar todavía 34 ducados y más de 17 gallinas. Teniendo en cuenta que las gallinas costaban aproximadamente 147 maravedíes en Andalucía en 1580, ${ }^{63}$ la deuda total ascendía a 15.250 maravedíes. Nada comparable con los 44.625 maravedíes que le debían. En cualquier caso, sus acreedores debían de ser compasivos, pues se trataba del cabildo que le daba trabajo y la cofradía de la que era hermano.

Hacia el final del testamento, a falta de hijos que reclamaran la legítima, Luis de Villafranca nombró a la cofradía y hospital de San Bernardo como su heredera universal. Además de todas las ganancias y deudas que quedaran por mencionar o pudieran surgir, el testador le destina concretamente sus posesiones más preciadas, a saber: la mula, sus gualdrapas y accesorios, el esclavo portugués y los libros y papeles (a buen seguro musicales). Sabedor de que eran los bienes de más valor de su casa, encargó venderlos para pagar su entierro y alguna necesidad que tuviera el hospital.

61 AHPdSE, PNS, oficio $1.1^{\circ}$ libro de 1568 , leg. 115 , fols. 763 r766v. AGAS, Archivo Hospital de Viejos (AHV), sección II, leg. 46, exp. 79.

62 RODRÍGUEZ VÁZQUEZ (1995): 72.

63 HAMILTON (1983): 355. 
Como era de esperar, sus albaceas fueron las personas que habían vivido más cerca de él. Por un lado Juan de Alanís, el hijo de su apreciada vecina. Por el otro, Andrés Mejías, que era suegro de éste y le habría enseñado su oficio de sastre. Terciaba el administrador del hospital de San Bernardo. También nombró como primer capellán de su capellanía, al estudiante Juan Mejía, hijo de Andrés Mejía y cuñado de Juan de Alanís, aun cuando el joven todavía no podía decir misa y necesitaba un asistente para ello. De hecho, en la documentación referida a esta capellanía en el hospital de San Bernardo, efectivamente Juan Mejía desempeñaba el cargo poco después, en enero de $1582 .{ }^{64}$ Los capellanes sucesivos serían nombrados por el hospital de San Bernardo, pero el testador se concedió esta licencia con el primero, probablemente como un gesto de deferencia más con Andrés Mejías.

\section{INVENTARIO DE BIENES}

Los que morían con la tranquilidad de haber hecho testamento eran una minoría social (aproximadamente el 18\%), porque la mayoría no tenía nada que legar. ${ }^{65}$ Adjunto al documento se encuentra el inventario de bienes post mortem ${ }^{66}$ anexo muy excepcional que acompañaba a pocos testamentos y era señal inequívoca de saludable situación económica. El inventario fue llevado a cabo por los albaceas al día siguiente de la escritura, el mismo día de óbito entonces, y presentado ante Diego de la Barrera Farfán, el escribano del testamento. Los bienes aparecen relacionados por orden de localización, pero no valorados. La vivienda estándar de la época no presenta una clara especialización de funciones por zonas, por lo tanto encontramos cualquier tipo de objeto en cualquier estancia, de acuerdo con las necesidades. ${ }^{67}$ Lo primero que los albaceas abrieron fue la despensa. Allí encontraron una cantidad indeterminada pero no muy bien valorada de trigo, cebada, alpiste, yeros, harina, garbanzos secos, una alquitara o alambique y unos frascos de "agua de olor", producto obviamente de lujo. Cualquiera de estos productos aparecen bajo el adjetivo de "poco/a", lo cual no describe las fanegas de trigo que el maestro había afirmado tener en su casa: "Yten mando a Francisco de Villafranca mi hermano clérigo presvítero seys fanegas de trigo del que tengo en mi casa".

64 AGAS, Archivo Hospital de Viejos (AHV), sección II, leg. 46, exp. 79 .

65 MARTÍNEZ GIL (1993): 579.

66 AHPdSE, PNS, oficio 1, leg. 150, libro $3^{\circ}$ de 1579, 23 de octubre de 1579 , fol. 646 .

67 RODRÍGUEZ VÁZQUEZ (1995): 115.
Después de revisar la despensa, los albaceas prosiguieron por la recámara, donde encontraron:

-Vestuario del maestro: calzas, jubón, botas, borceguíes, sayo, medias calzas, sotana, camisas, camisón. En este conjunto son reconocibles las calzas para uno de sus sobrinos. En esta recámara, el maestro guardaba la ropa que tenía en uso cotidiano, pues alguna se califica como "vieja". En el arca ensayalada que había legado a Beatriz Castaño había lienzos que no se inventariaron porque no era necesario. Entre los tejidos de los que estaban hechas las prendas enumeradas, se menciona paño, camelote o tejido fuerte de lana, lienzo, estameña, tafetán y red.

-Ropa de cama: guadamecíes, frazadas, sábanas, colchones, paños, almohadas, colchas, a lo que hay que añadir mantel y toallas, algunas de estas cosas "viejas" o "muy viejas".

-Muebles: escabel, mesa de lavar, mesa, bancos, sillas, aparador, un arca vieja al parecer propiedad de la liberta de color.

-Utensilios domésticos: todos referidos a la cocina. Acetre, cedazos, plato de azófar, sartén, lebrillo.

-Alimentos almacenados: "un costal con un poco de trigo", cuya expresión de cantidad tampoco sugiere las suficientes fanegas para satisfacer sus disposiciones testamentarias.

En la tercera estancia, una "pieça vaja", fueron localizados objetos de la misma naturaleza variada: dos sillas, un dosel de lienzo blanco, guadameciles y una nueva arca ensayalada llena de prendas de poco uso, que el maestro reservaría para ocasiones especiales. El contenido de este arca sí se desvela, incluyendo la sotana y el manto negros nuevos que el difunto había prometido a su hermano y las calzas y los calzones de estameña negra destinados a sus sobrinos. Además había otro manto de paño, otro de burato, un herreruelo negro, una ropilla corta, un sombrero llano de clérigo, y paño para hacer unas mangas. La pieza más valiosa de la sala es el harpa, el único objeto del inventario que está vinculado con la profesión del difunto. El hecho de que sea un instrumento polifónico (se entiende arpa de dos órdenes, la más frecuente en el Renacimiento) ${ }^{68}$ demuestra la formación musical de Luis de Villafranca y la tarea de composición que habría llevado a cabo cuando era maestro de capilla. De hecho, al no contar un repertorio propio, el arpa desempeñó un papel esencial en el intercambio de repertorios entre la vihuela y los instrumentos de tecla. ${ }^{69}$

En la cuarta sala, que no era otra cosa que un corral, los albaceas encontraron los aparejos de la mula (silla, dos

68 CALVO-MANZANO (1986).

69 GRIFFITHS, 4, 2 (Zaragoza, 1988): 59-78. 
gualdrapas, guarniciones) y el ganado aviar, afortunadamente contabilizado: 8 palomas, 2 capones y 30 pollos y gallinas. Estas 40 aves, si le aplicamos el coeficiente aproximado de precios del año 1580 , montarían una cantidad variable entre 2.088 y 5.884 maravedíes, dependiendo de la medida en que se emplee el precio de pollo $(52,2)$ o el de gallina $(147,1) .^{70}$

En la bodega se encontró un nuevo conjunto abigarrado de objetos:

-Otra remesa de víveres, destinados a Beatriz Castaño: $3 / 4$ de vino (que valoramos aproximadamente en 111,75 maravedíes), 1/4 de vinagre (unos 25 maravedíes), dos tinajuelas de aceituna, otra pequeña de aceite, un poco de carbón y algunas cebollas.

-El menaje del hogar también se acumulaba en esta bodega: un candelero de azófar, un lebrillo viejo, tres calderas de diferentes tamaños, alquitara, trébedes, asadores, tinajas para el agua y ocho esteras.

-Las posesiones animadas de más valor: el esclavo portugués negro llamado Pedro y la mula negra con sus guarniciones viejas. Tenemos constancia documental de que a los tres días, el lunes 26, un miembro del hospital de San Bernardo vendió al remate la mula ensillada y con su gualdrapa ante notario. El precio del que se partía eran 20 ducados, puesto que eso era lo que se había ofrecido en la feria de ganado. Un vecino de Sevilla ofreció 24 ducados y la compró, sin que tengamos noticia de que otra persona pujase. $^{71}$

A grandes rasgos, dentro de este inventario de bienes distribuido en cinco estancias, ya que podemos valorar numéricamente los grupos de posesiones, al menos distingamos entre ellos desde el punto de vista del volumen. En esta larga enumeración hemos encontrado 19 ítems diferentes referidos a despensa, 32 utensilios domésticos (fundamentalmente de cocina y de iluminación), 16 muebles, 24 prendas de ropa doméstica (en su mayoría referida a la cama) y 22 prendas de vestir. El contenido del arca ensayalada de ropa de lienzo que heredó la familia Alanís puede adscribirse a un grupo textil o al otro. Como se puede comprobar, existe un gran equilibrio entre las cinco secciones.

Entre los muebles, destacan las tres arcas, que desempeñaban el papel de armario y de caja fuerte. Eran transportable y no tenían por qué costar más de 300 maravedíes. Las sillas, en comparación con los bancos y las mesas, eran caras, y el maestro tenía cuatro viejas y dos nuevas. ${ }^{72}$ No se menciona la cama, pero no hay que entender que yacía en

70 HAMILTON (1983): 355.

71 AHPdSE, PNS, oficio 1, leg. 150, libro $3^{\circ}$ de 1579, 26 de octubre de 1579, fol. 681 .

72 RODRÍGUEZ VÁZQUEZ (1995): 117-128. un colchón apoyado en el suelo, porque en cambio sí tenía cielos de cama.

A todo lo cual hay que añadir los cinco que pueden ser considerados bienes de lujo: el arpa, el esclavo, la mula con sus arreos, las 40 aves y los frascos de perfume. Se puede especular sobre si los dos negros que vivían con el maestro, a los que él les lega algo de ropa, también fueron sus esclavos y ya los había liberado. La esclavitud en el Mediterráneo en el siglo XVI aparece ligada al servicio doméstico de carácter personal y suntuario, para el cual la raza negra resultaba prestigiosamente exótica. Entre los esclavos hay muchos moriscos y berberiscos, pero dominan los negros, cuya esclavitud era la que presentaba menos conflictos morales. Muchos esclavos eran manumitidos cuando ya no eran útiles, o a la muerte del amo o para que se casaran. ${ }^{73}$ En particular, la población africana en Sevilla era muy nutrida desde el siglo XV, en torno a un 3,7\% de la población hispalense, pero en la segunda mitad del siglo XVI llegará al 8\%, de los cuales los subsaharianos podrían suponer un $68 \% .^{74}$ La Casa de Contratación era el principal centro de distribución de esclavos a nivel nacional e internacional, mercancía que aportaban principalmente los comerciantes portugueses que detentaban el monopolio de las costas africanas, pero además en la ciudad existía una enorme demanda de mano de obra esclava que absorbía el $85 \%$ de los cautivos que permanecían en España ${ }^{75}$ Por lo tanto, en Sevilla no resulta tan llamativo encontrar esclavos negros en posesión de dueños no particularmente acaudalados.

Con todo, no se puede afirmar que éste fuera el inventario postmortem de una economía privilegiada. Brillan por su ausencia algunos bienes característicos de la opulencia: los metales preciosos y las joyas, las obras de arte, los tejidos de lujo como la seda y el terciopelo, el carruaje, la ganadería mayor, las sustancias ultramarinas (tabaco, ámbar, almizcle, etc). No podemos calcular cuál era el valor de su capital, pero si no supera los cinco millones no se puede considerar otra cosa que un inventario pobre. ${ }^{76} \mathrm{La}$ base de su riqueza se concentra en su propiedad inmobiliaria (su vivienda urbana), la inversión en tributos y sus deudas a favor. Los inventarios de bienes de los clérigos sevillanos estaban por debajo de los de los mercaderes, pero su soltería jugaba en favor de su bienestar. Todos tenían algún esclavo e invertían en censos, lo cual coincide con el maestro Villafranca, pero los clérigos

73 Ibídem: 45-49.

74 COLLANTES DE TERÁN (1984). DOMÍNGUEZ ORTIZ (1974): 179. CORTÉS LÓPEZ (1989): 201-204. FERNÁNDEZ CHAVES y PÉREZ GARCÍA (2010): 6.

75 FERNÁNDEZ CHAVES y PÉREZ GARCÍA (2009): 85. 76 AGUADO DE LOS REYES, Jesús (1994): 40. 
solían destacar por su gasto en ropa, ajuar y arte. ${ }^{77}$ De todas formas, es habitual que los inventarios postmortem en general llamen la atención por la modestia en cuanto a capital invertido en bienes muebles del hogar y vestuario. ${ }^{78}$

$\mathrm{El}$ inventario de sus bienes nos revela algunos aspectos de la vida y la personalidad del maestro Villafranca. La moda y las vanidades mundanas parecen haber tenido escasa influencia sobre su forma de vida. Probablemente vivió de forma austera, lo cual lo convierte en un buen exponente del tono moral de los clérigos españoles en el período pretridentino, bajo la influencia de las precoces reformas realizadas en tiempos de los Reyes Católicos. Además de que carecía de obras de arte, objetos devocionales y ropa nueva, a excepción del conjunto negro que legó a sus familiares, que era nuevo y reservado con toda probabilidad a las ocasiones especiales. Por el contrario, en el inventario de bienes aparece la palabra "viejo/a" en trece ocasiones, lo cual revela que el maestro tendía a conservar los objetos en uso durante muchos años, hecho explicable por su avanzada edad. Es una lástima que el inventario no nos ayude a conocer a qué nivel intelectual leía Luis de Villafranca, cuántos libros poseía y de qué temática. $\mathrm{Al}$ menos sabemos que tenía una biblioteca y un archivo domésticos.

\section{MÁS ALLÁ DEL TESTAMENTO}

Así pues, a juzgar por el testamento y documentos adyacentes se pueden apuntar algunos datos para trazar un perfil social del personaje. Desde luego, existen limitaciones. Ignoramos todo sobre los orígenes sociales de Luis de Villafranca. No sabemos de dónde procedía ni a qué se dedicaba su padre. Tan sólo contamos con que al menos había tenido un hermano presbítero y una hermana, y que su sobrino nieto era talabartero. El dato de que en 1532 estuviera trabajando en la catedral del Plasencia como maestro de capilla no nos invita a dar por hecho que fuese oriundo de aquella zona o que se hubiera formado en esa sede, habida cuenta de la itinerancia de los músicos, aun los mejores y más solicitados como fue Francisco Guerrero. Incluso los mozos de coro y seises de una catedral eran seleccionados en virtud de sus cualidades a lo largo y ancho del territorio nacional. Lo que sí podemos sospechar era que si el maestro murió en 1579 y en 1532 era maestro de capilla en Palencia, debió de morir a una edad muy avanzada y desempeñó la maestría de capilla en Plasencia con precocidad, en la plenitud de su juventud, entre los 20 y los 30 años. Lo cual nos revela una sólida

77 RODRÍGUEZ VÁZQUEZ (1995): 76-77.

78 Ibídem: 179. formación musical y humanística en la infancia, por ende un temprano entronque en la carrera catedralicia, y un nivel de vida próspero a lo largo de su longeva existencia.

En cuanto a su formación, para ser docente de canto llano en la catedral, y probablemente de otras materias humanísticas, a la fuerza debía ser un hombre letrado. No nos consta una titulación universitaria, porque en ese caso hubiera sido frecuente adjuntar la palabra "licenciado" a "clérigo" y "presbítero". No obstante, sí nos consta su competencia gráfica. Como se puede observar, su caligrafía era muy ágil y suelta. Por ser maestro de capilla y docente, se le supone una formación humanística y musical sólida. Como para confirmarlo, su escritura se adscribe enteramente al modelo gráfico humanístico, constituyendo su rúbrica personal un ejemplo de firmeza en el trazo, módulo pequeño, rectitud de líneas y pulcritud, por lo demás. Todo ello teniendo en cuenta que trazó esta firma al pie de su testamento horas antes de morir, sorprende la precisión de sus trazos.

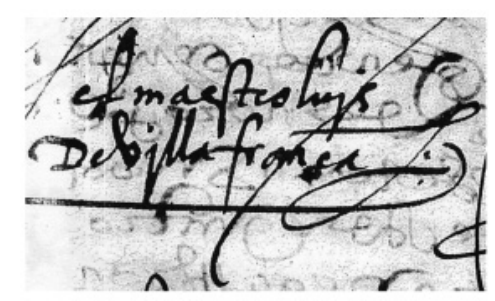

Fuera cual fuera el lugar de su formación, parece obvio que se trataba de una sede catedralicia. El cauce más oficial y más recomendable para convertirse en músico en el Antiguo Régimen consistía en ser seleccionado durante la infancia como cantorcillo de una capilla musical eclesiástica, donde se adquiría una educación tanto en letras como en música a lo largo de varios años. Los contratos privados de aprendizaje no se producían para la enseñanza de los entresijos del arte musical, sino para fines más prácticos: la adquisición de un oficio de cantor o instrumentista. Antes de que nacieran los conservatorios, las catedrales llevaron a cabo el único programa reglado de enseñanza musical en Europa. La formación teórica musical tenía lugar en el marco del Quadrivium universitario. Por su parte, la práctica no sólo era impartida en la capilla de San Nicolás de la catedral de Sevilla para los mozos de coro y seises, sino también para cualquier miembro del personal catedralicio que tuviera interés en aprender. Lo cual no sólo atraía a los aficionados, sino a todos los miembros de coro o capellanes, puesto que el canto llano formaba parte del Oficio Divino más cotidiano.

Luis de Villafranca, como otros músicos clérigos de las capillas musicales, no se identificaba como músico ante la sociedad, sino como presbítero. El ordenamiento religioso 
frecuentemente suponía otra fuente de ingresos para los músicos, y entre los cantores y maestros de capilla hay un alto porcentaje de clérigos que se aferran a su condición por su prestigio social. En su recuento de músicos a través de los censos, Miguel Ángel Marín encontró la dificultad de que muchos músicos jaqueses del siglo XVIII eran irreconocibles porque aparecían como clérigos en los censos, lo cual nos revela cierto problema de autopercepción de los músi$\cos .{ }^{79}$ Los sacristanes de las parroquias, por ejemplo, podían ser sus organistas, o músicos en alguna de las compañías de la ciudad, pero en los catastros sólo aparecen por su profesión principal. Es cierto que algunas fuentes revelan una imagen peyorativa del músico en la sociedad, pero otras los valoran como buenos profesionales, sobre todo a los compositores, maestros de capilla y organistas ordenados.$^{80}$ Los grandes polifonistas eran reverenciados como artistas por su formación intelectual, aunque carezcan de estudios universitarios. Ya que el maestro Villafranca se inscribe indudablemente en este grupo en virtud de su obra didáctica editada, no parece lógico que se avergonzase de su profesión, pero lo cierto es que en la documentación privada siempre sitúa sus actividades musicales en un segundo plano. Incluso puede sospecharse que su titulación testamentaria (maestro de capilla) revelara una frustración profesional íntima de no haber logrado ejercer dicho cargo en el año de su muerte.

En lo referente a la economía, este testamento y su inventario de bienes da la impresión de una situación económica saludable, de modesta prosperidad, pero tampoco demasiado holgada. El maestro contaba con una casa en propiedad, otra subarrendada, una cabalgadura, un esclavo negro, ganado aviar, sus deudas se compensan en más del doble con el dinero que le debían a él. El testamento y la documentación notarial demuestran que el maestro estaba en condiciones de realizar inversiones y operaciones financieras, aunque su salario, uno de los más discretos del personal musical de la catedral de Sevilla, nos hiciera temer lo contrario. Está demostrado documentalmente que los maestros, cantores y ministriles invertían en el comercio con las Indias, detentaban juros, llevaban a cabo tareas administrativas por cuenta de monasterios, arrendaban impuestos, etc.

Por lo que sabemos de Luis de Villafranca, sus ahorros le permitieron comprar su casa de cinco estancias y dos plantas de la calle Rosas o Granadales a Juan de Chillas en 1568 y redimir los tributos que tenía situados. Por otras fuentes sabemos que Luis de Villafranca compró en 1566 un tributo de 3.750 maravedíes (10 ducados) anuales sobre unas casas

79 MARÍN LÓPEZ (2002): 34.

80 BEJARANO PELLICER (2013): 107-114. de las hermanas doncellas Juana de Zamudio y María Ortiz, vecinas de la collación de san Martín. Aun cuando las casas fueron vendidas en 1569 a Agustín de Castro, el tributo siguió correspondiendo a Luis de Villafranca. ${ }^{81}$ De todas formas, eso no habla tanto de su capacidad inversora como de la fuente adicional de rentas que hay que sumar a su salario para calcular su poder adquisitivo.

Posteriormente, en noviembre de 1571 compró al presbítero Luis de Medina, el cual tenía extensas propiedades en la collación de San Julián, un tributo que le suponía 803 maravedíes y medio al año, pagados por tercios, que éste tenía situados sobre una casa de su propiedad, dividida en dos, en el mismo barrio. Por este tributo, Luis de Villafranca tuvo que desembolsar 30 ducados, los cuales ya había pagado adelantados para redimir el tributo de 1.500 maravedíes al año, que pesaba sobre las casas que él había comprado anteriormente a Luis de Medina sin saberlo. Cuando había descubierto la renta que se veía obligado a pagar al organista Diego Marín a causa de esa compra, Luis de Villafranca había redimido el tributo y pedía cuentas a Luis de Medina. Éste le vendió a él un tributo ya mencionado de 803 maravedís y medio para recompensarle por los 30 ducados que el maestro de mozos de coro ya había desembolsado. Este nuevo tributo podía ser redimido por Luis de Medina o sus sucesores cuando quisieran, y si pasaba dos años sin pagar sus beneficios, Luis de Villafranca tendría derecho a apropiarse de las casas en las que estaba situado. Éstas tenían que estar bien mantenidas y sólo podrían ser vendidas a un laico después de que Villafranca las declinara ${ }^{82}$

En mayo de 1572 compró unas casas en un callejón adyacente a la calle Sierpes, el Azofeifo, en pleno corazón de Sevilla, a las herederas de Rodrigo Albarracín (madre y viuda) por un precio de 371 ducados y medio, de las cuales tomó posesión ante notario un mes después ${ }^{83}$ Estaban dotadas de pozo, corral y soberados. Estas casas tenían un inquilino por dos vidas, el guarnicionero de espadas Ginés de Fontes con su mujer, que pagaba 14.000 maravedíes al año de renta. Además, sobre las casas pesaba un tributo redimible de 10.714 maravedíes al año que había que pagar al monasterio de Madre de Dios. Por lo tanto, la verdadera renta se le quedaba en poco más de 3.000 maravedíes al año. En el momento de su muerte, el comprador ya había redimido los $400 \mathrm{du}$ cados de principal de ese tributo. El maestro Villafranca pagó el precio en varios pagos: 140 ducados los pagó cediendo el tributo que en 1566 había comprado a las hermanas Juana de

81 AHPdSE, PNS, oficio 1 , libro $1^{\circ}$ de 1570 , leg. 121,4 de febrero de 1570 , fols. 481 r-482r.

82 AHPdSE, PNS, oficio 1, libro $3^{\circ}$ de 1571, leg. 126, fols. 191 83 AHPdSE, PNS, oficio 1 , libro $2^{\circ}$ de 1572 , leg. 128 , fol. 580. 
Zamudio y María Ortiz, otros 80 ducados los pagó cediendo los tributos que había comprado a Luis de Medina en 1569 y en 1571,30 ducados que abonó al contado ${ }^{84}$ y otros 72 que le quedaron debiendo y que se comprometió a pagar en tres meses. ${ }^{85}$ Puesto que este inmueble no aparece en el testamento, Luis de Villafranca debió de venderlo antes de 1579 a pesar de que en él había invertido tantos bienes.

Como sabemos, en el momento de su muerte, el maestro Villafranca también tenía en su poder un inmueble del hospital de San Bernardo, situado en la plazuela de las tiendas de la collación de la Magdalena, concedido en arrendamiento por dos vidas y subarrendado a un batihoja por 23 ducados al cuatrimestre. Más allá de las necesidades de alojamiento, la vivienda se convirtió en una fuente de ingresos y una inversión para los músicos. ${ }^{86}$ En la floreciente economía sevillana, el mercado inmobiliario ofrecía grandes posibilidades de enriquecimiento gracias al aumento de los alquileres, el espectacular incremento de la población y la revolución de los precios. ${ }^{87}$

Por añadidura, el maestro Villafranca se revela con admirables dotes de acreedor. Además de lo que aparece en el testamento (Luis de Medina y el anterior subarrendatario), en noviembre y diciembre de 1568 , cedió poderes a dos vecinos de Granada, padre e hijo, para que se encargasen de cobrar o hacer cobrar 31 ducados que el granadino Alonso de Valdearenas debía a Luis de Villafranca, no sabemos por qué concepto. ${ }^{88}$ En marzo de 1569 recibía 70 ducados del sastre Cristóbal Rodríguez, vecino de Sevilla en la collación de san Román, cuya deuda se veía obligado a pagar porque Luis de Villafranca había conseguido una carta requisitoria de la Real Audiencia. ${ }^{89}$

La fundación de una capellanía y el encargo de 1 misa cantada y 127 misas rezadas lo describen como una persona preocupada por la salvación de su alma, pero sin salirse de lo común. Se puede apreciar que las personas que rodean a este clérigo sin apenas familia son sus vecinos, los que habían tenido trato personal con él. La cofradía de la que era hermano se ha convertido en su familia y le ofrece una garantía de perpetuidad en el cuidado de su alma.

Sin atrevernos a elevarlo a modelo de músico clérigo de la catedral de Sevilla en el siglo XVI, este cúmulo de documentos de la naturaleza más privada nos permite carac-

84 Ibídem, fols. 290r-295r.

85 Ibídem, fol. 295v.

86 BEJARANO PELLICER (2013): 85-88.

87 PIKE (1978): 113. y $907 \mathrm{v}$.

88 AHPdSE, PNS, oficio 1 , libro $3^{\circ}$ de 1568 , leg. 117 , fols. 849 763 r. terizar eficazmente a Luis de Villafranca como miembro de un grupo social, el de los músicos clérigos urbanos del Renacimiento. El contraste de la documentación institucional con la notarial descubre realidades interesantes que afectan a la adscripción social y las condiciones laborales de los músicos. Lo cual puede ayudar a explicar y a contextualizar aspectos de su actividad musical. En el caso de nuestro maestro y tratadista de canto llano, esperamos que su trayectoria vital contribuya a esa Historia social de los músicos en el Renacimiento que todavía está por hacerse. En el peor de los casos, servirá para poner de manifiesto que el Renacimiento musical español fue llevado a cabo por personas plenamente integradas en la vida social y económica de las ciudades, y que por muy anónimos que se les considere, son sujetos potencialmente historiables.

\section{BIBLIOGRAFÍA}

Aguado de los Reyes, Jesús, Riqueza y sociedad en la Sevilla del siglo XVII. Sevilla, Universidad de Sevilla y Fundación Fondo de Cultura de Sevilla, 1994.

Barrios Manzano, María del Pilar, "Las funciones de chantre, sochantre y maestro de canto llano en la catedral de Coria (Cáceres). 1590-1750", Cuadernos de Arte de la Universidad de Granada, 26 (Granada, 1995), 73-82.

Bejarano Pellicer, Clara, El mercado de la música en la Sevilla del Siglo de Oro. Sevilla, Universidad de Sevilla, Fundación Focus-Abengoa, 2013.

Calvo-Manzano, María Rosa, El arpa en el Renacimiento español. Madrid, Fundación Banco Exterior, D. L., 1986.

Carmona García, Juan Ignacio, El sistema de la hospitalidad pública en la Sevilla del Antiguo Régimen. Sevilla, Diputación de Sevilla, 1979.

Carmona García, Juan Ignacio, Las redes asistenciales en la Sevilla del Renacimiento. Sevilla, Universidad de Sevilla, 2009.

Collantes de Terán, Antonio, Sevilla en la Baja Edad Media: la ciudad y sus hombres. Sevilla, Ayuntamiento de Sevilla, 1984.

Collantes de Terán, Francisco, Los establecimientos de caridad de Sevilla, que se consideran como particulares: apuntes y memorias para su historia. Sevilla, Oficina de El Orden, 1886.

Collantes de Terán, Francisco, La Capilla de Escalas en la Santa Metropolitana y Patriarcal Iglesia de Sevilla. Sevilla, Carlos de Torres y Daza, 1890.

Cortés López, José Luis, La esclavitud negra en la España peninsular del siglo XVI. Salamanca, Universidad de Salamanca, 1989. 
De la Rosa y López, Simón, Los seises de la catedral de Sevilla. Sevilla, Francisco de P. Díaz, 1904.

Domínguez Ortiz, Antonio, El Antiguo Régimen: Los Reyes católicos y los Austrias. Madrid, Alianza, 1974.

Edler, Arnfried, "The social status of organists in Lutheran Germany from the $16^{\text {th }}$ through the $19^{\text {th }}$ century", Walter Salmen (ed.), The social status of the professional musician from the Middle Ages to the 19th century, Nueva York, Pendragon, 1983.

Fernández Chaves, Manuel F. y Pérez García, Rafael M., En los márgenes de la ciudad de Dios: moriscos en Sevilla. Granada, Valencia y Zaragoza, Universidad de Zaragoza, 2009.

Fernández Chaves, Manuel F. y Pérez García, Rafael M., "Las redes de la trata negrera: mercaderes portugueses y el tráfico de esclavos en Sevilla (c. 1560-1580)", Aurelia Martín Casares y Margarita García Barranco (comps.), La esclavitud negroafricana en la historia de España. Siglos XVI y XVII, Granada, Comares, 2010, 5-34.

Fernández Rojas, Mercedes, "Los mínimos de San Francisco de Paula en Sevilla durante los siglos XVI al XIX", Valeriano Sánchez Ramos (coord.), Los mínimos en Andalucía: IV Centenario de la fundación del Convento de Nuestra Señora de la Victoria de Vera (Almería), Almería, Instituto de Estudios Almerienses, 2006, 149-186.

Gembero Ustárroz, María, "Migraciones de músicos entre España y América (siglos XVI-XVIII): estudio preliminar", María Gembero Ustárroz y Emilio RosFábregas (coords. y eds.), La música y el Atlántico. Relaciones musicales entre España y Latinoamérica, Granada, Universidad de Granada, 2007, 17-58.

Gómez Pintor, María Asunción, "Fuentes documentales inéditas sobre la figura del polifonista Juan Navarro, el Hispalensis", Cuadernos de Arte de la Universidad de Granada, 26 (Granada, 1995), 27-46.

González Barrionuevo, Herminio, Francisco Guerrero (1528-1599) vida y obra. La música en la catedral de Sevilla a finales del siglo XVI. Sevilla, Cabildo Metropolitano de la Catedral de Sevilla, 2000.

Granger, Sylvie, Musiciens dans la ville (1600-1850). París, Belin, 2002.

Griffiths, John, "La música renacentista para instrumentos solistas y el gusto musical español", Nassarre, 4, 2 (Zaragoza, 1988), 59-78.

Hamilton, Earl, El tesoro americano y la revolución de los precios en España (1501-1650). Barcelona, Ariel, 1983.

Marín López, Miguel Ángel, Music on the margin. Urban musical life in eighteen century Jaca (Spain). Kassel, Reichenberger, 2002.
Marín López, Miguel Ángel "Familia, colegas y amigos. Los músicos catedralicios de la ciudad de Jaca durante el siglo XVIII", en Andrea Bombi, Juan José Carreras y Miguel Ángel Marín (eds.), Música y cultura urbana en la Edad Moderna, Valencia, Universidad de Valencia, 2005, 115-144.

Marín López, Javier, "Música y músicos navarros en el Nuevo Mundo: algunos ejemplos mexicanos (siglos XVIXIX)", Príncipe de Viana, 238 (Pamplona, 2006), 425-458.

Martín Galán, Jesús, "Villafranca, Luis de", Casares Rodicio, E. (dir. y coord.), Diccionario de la música española e hispanoamericana, Madrid, Sociedad general de autores y editores, 2002, vol. 10, 909.

Martínez Gil, Fernando, Muerte y sociedad en la España de los Austrias. Madrid, Siglo XXI, 1993.

Moll Roquetas, Jaime, "Cristóbal de Morales en España. Notas para su biografía", Anuario musical, 8 (Barcelona, 1953), 3-26.

Moreno Toral, Esteban, Estudio social y farmacoterapéutico de la lepra: el Hospital de San Lázaro de Sevilla (s. XIII-XIX). Sevilla, Diputación de Sevilla, Área de Cultura y Ecología, 1997.

Morgado, Alonso de, Historia de Sevilla. Sevilla, Andrea Pescioni y Juan de León, 1587. Ed. Facsímil: Sevilla, Colegio Oficial de Aparejadores y Arquitectos Técnicos de Sevilla, 1981.

Ortiz de Zúñiga, Diego, Anales eclesiásticos y seculares de la muy noble y muy leal ciudad de Sevilla. Madrid, Imprenta Real, Juan García Infançón, 1677.

Pike, Ruth, Aristócratas y comerciantes. La sociedad sevillana en el siglo XVI. Barcelona, Ariel, 1978.

Reynaud, François, "Música y músicos toledanos: grupos e individuos fuera de la catedral", John Griffiths y Javier Suárez-Pajares (eds.), Políticas y prácticas musicales en el mundo de Felipe II, Madrid, ICCMU, 2004, 241252.

Rodríguez Vázquez, Antonio Luis, Ricos y pobres. Propiedad y vida privada en la Sevilla del siglo XVI. Sevilla, Ayuntamiento de Sevilla, 1995.

Rubio Merino, Pedro, "Inventario del hospital de San Bernardo, vulgo de los Viejos de Sevilla", Archivo Hispalense, 180 (Sevilla, 1976), 1-35.

Ruiz Jiménez, Juan, "Ministriles y extravagantes en la celebración religiosa", John Griffiths y Javier Suárez-Pajares (eds.), Políticas y prácticas musicales en el mundo de Felipe II, Madrid, ICCMU, 2004, 199-242.

Ruiz Jiménez, Juan, "Radiografía socioprofesional de los oficios musicales en el siglo XVIII. Granada en el catastro de Ensenada (1752)", Andrea Bombi, Juan José 
Carreras y Miguel Ángel Marín (eds.), Música y cultura urbana en la Edad Moderna, Valencia, Universidad de Valencia, 2005, 150-151.

Siemens Fernández, Lothar, "Martín de Silos (1564-1618), un destacado ministril y maestro de capilla aragonés en la catedral canaria de Santa Ana”, Nassarre, 23, 1 (Zaragoza, 2007), 109-128.
Stevenson, Robert, La música en la Catedral de Sevilla 1478-1606: documentos para su estudio. Madrid, Sociedad Española de Musicología, 1985.

Stevenson, Robert, La música en las catedrales españolas del Siglo de Oro. Madrid, Alianza Editorial, 1993.

Recibido: 13.02.2012

Aceptado: 03.05.2016 